\title{
ALK NP_004295.2:p.M1166R
}

National Cancer Institute

\section{Source}

National Cancer Institute. ALK NP 004295.2:P.M1166R. NCI Thesaurus. Code C133489.

A change in the amino acid residue at position 1166 in the ALK tyrosine kinase receptor protein where methionine has been replaced by arginine. 